\title{
Fifte Session
}

\section{Saturday, April 26, 1969, at 9:40 a.m.}

\section{BUSINESS MEETING}

Pursuant to the notice of the meeting published in the January, 1969, issue of the American Journal of International Law, the business meeting of the American Society of International Law convened at 9:40 o'clock a. $\mathrm{m}$. in the State Room of the Mayflower Hotel, Washington, D. C., OscaR Schachter, President of the Society, presiding.

Judge Edward Dumbauld, Secretary of the Society, read the list of members who had died during the year.

\section{In Memoriam}

Eugene D. Bennnetri, San Francisco, California, member since 1950, died December, 1968.

Israkl Bernstein, Portland, Maine, member since 1965, died June, 1967. Frank X. Brown, Washington, D. C., member since 1968, died May 1, 1968. Josept M. Cunningham, Brooklyn, New York, member since 1968, died December, 1968.

Allen W. Dulles, Washington, D. C., member since 1923, died January $1,1969$.

NwIr Clark Godfrey, New York, N. Y., member since 1957, died July 15, 1968.

Walter Herzferd, New York, N. Y., member since 1951, died December, 1968.

Ervin Hexner, State College, Pennsylvania, member since 1944, died September 10, 1968.

Frank B. Higains, S. J., Kansas City, Missouri, member since 1959, died May 5, 1968.

AlFred KARGER, Quito, Ecuador, member since 1943, died November 1, 1968.

John M. Keesing, New York, N. Y., member since 1955, died September 18, 1968.

Chiping H. C. Kiang, Larchmont, New York, member since 1950, died September, 1968.

Xavier Kimfer-Marchand, Lima, Peru, member since 1959, died April 14, 1968.

KarL E. LachmanN, Kew Gardens, New York, member since 1953, died Angust 29, 1968.

Phombe Morrison, Chester, Connecticut, member since 1929, died September 30, 1968.

ElizabeTH Nowinskr, Washington, D. C., member since 1960, died August 26, 1968. 
Wrimam A. Schnader, Philadelphia, Pennsylvania, member since 1960, died March, 1968.

Thresa Schmatz, New York, N. Y., member since 1946, died November 12, 1968.

Otto SchoenRich, New York, N. Y., member since 1917, died January 10, 1968.

Vytautas Stasinskas, New York, N. Y., member since 1965, died April 29, 1968.

Ira Jewell Wrluams, Philadelphia, Pennsylvania, member since 1917, died February 25, 1969.

The members rose and observed a moment of silence in memory of the deceased.

Secretary Dumbauld then read the names of the following members of the Society who had completed fifty years as members, and declared them Members Emeriti:

Henry I. Dockweurar, Los Angeles, California, member since November 26, 1919.

Stanley P. Smith, Oakland, Maryland, member since December 16, 1919.

Theodore H. Thiesing, New York City, member since December 27, 1919.

Mr. Stephen M. Schwebel, Executive Director of the Society, reported on the Society's activities during the past year. He stated that the year had been a successful one, the Society having sponsored thirteen regional meetings, which were well attended and of good quality. The Society had expended more money for the meetings, which the results seemed to justify.

The study panels of the Board of Review and Development had been very active and a substantial number of articles and books based on the panel discussions were in various stages of development. The panel on Civil Wars, which had been meeting for several years with the assistance of a grant from the Carnegie Corporation, has in preparation a volume of seven monographs on the rôle of international law in particular civil wars, to be published by the Johns Hopkins Press. Several new panels had been set up to deal, among other subjects, with international monetary policy, international movement of national art treasures, humanitarian law, reprisal and retaliation in international law, and regimes of conflict control.

The Board of Review and Development also had initiated a special meeting to consider the legal implications of the Peruvian expropriation of the International Petroleum Company, and of draft legislation on sovereign immunity.

Mr. ScHwaber called attention to the questionnaire circulated to members of the Society inviting comments on its work and suggestions for its improvement. He also called attention to the increase of over $10 \%$ in the membership during the year, and stated that the membership list had been computerized. This process involved many problems and numerous errors, 
but the list was now in good shape. It was intended not to publish the list as in the past but to make it available to reputable publishers for a price.

The Executive Director reported that there had been a substantial increase in subscriptions to International Legal Materials in response to the special introductory price offered this year and the mailing of the January issue of I.L.M. to all members and subscribers to the American Journal of International Law receiving the January issue of the Journal. Steps had also been taken to increase advertising in the Journal without appreciable results so far. Sales of the Cumulative Index 1941-1960 had been substantial, but it was not certain that the Society would recover all its costs.

The financial condition of the Society is good, though much depends on obtaining further foundation grants. The Henry Luce Foundation and the Avalon Foundation had provided grants during the year, the Luce Foundation grant making it possible to add to the Society's staff $\mathbf{M r}$. James A. R. Nafziger, who will act as Executive Secretary of the Association of Student International Law Societies and as National Administrator for the International Moot Court competition. Mr. ScHwEBer stated that the National Administrator for the current year, Mr. Allan R. Roman, had done a remarkable job. The position of Executive Secretary of the student association is to be rotated as an annual fellowship over a threeyear period under the Luce grant.

The Avalon Foundation grant was for general support and was used largely for promotional activities of the Society.

President ScHachter expressed the Society's appreciation to the Executive Director and the Society's staff for their work during the past year.

There followed extended discussion of the usefulness and availability of the Society's membership list to members and to commercial publishers, some members proposing that a new edition of the list be published. The costs involved were also considered, and it was the consensus of the meeting that the list be printed and distributed to all members every two years. Upon motion duly made, seconded and carried, it was decided that the question of reproducing the list, with various alternative methods of doing so, be referred to the Executive Committee of the Society for decision.

The meeting next considered the unanimous report of the Committee on Annual Awards recommending that the Society's Certificate of Merit be awarded to Professor Richard A. Falk for his book, Legal Order in a Violent World. The recommendation was adopted unanimously.

Professor Oliver J. Lissitzy , Chairman of the Committee on Selection of Honorary Members, reported the recommendation of the committee that Professor Charles Rousseau of the Faculty of Law of the University of Paris, Director of the Institut des Hautes Etudes Internationales, and Editor of the Revue Générale de Droit International Public, be elected an honorary member of the Society. The recommendation was unanimously adopted and Professor Rousseau elected an honorary member. 
The next order of business was the election of officers. President SchachTER retired from the chair, which was assumed by Judge Edward Dumbauld, Secretary of the Society. The Report of the Nominating Committee was presented, and upon motion duly made, seconded and carried, the report was accepted and the following declared elected for the coming year:

Honorary President: Philip C. Jessup.

President: Oscar Schachter.

Vice Presidents: Richard R. Baxter, Harold D. Lasswell, Monroe Leigh, Stephen M. Schwebel.

Honorary Vice Presidents: Dean G. Acheson, William W. Bishop, Jr., Herbert W. Briggs, Arthur H. Dean, Hardy C. Dillard, Charles G. Fen. wick, Green H. Hackworth, James N. Hyde, Hans Kelsen, Brunson MacChesney, Charles E. Martin, Myres S. McDougal, Amos J. Peaslee, John R. Stevenson, Robert R. Wilson, Quincy Wright.

Members of the Executive Council to serve until 1972: George H. Aldrich, District of Columbia; William Conant Brewer, Jr., Massachusetts; A. Broches, District of Columbia; John Carey, New York City; Richard B. Lillich, Virginia; Saul Mendlovitz, Massachusetts; Ved P. Nanda, Colorado; Robert W. Tucker, Maryland.

President Schachter thereupon resumed the chair. He expressed his appreciation of the honor and privilege of serving as President of the Society as well as of the co-operation of the members of the Society on the committees and panels. He expressed particular appreciation of the work of the Executive Committee members in their devotion and attention to the Society's affairs.

Upon the recommendation of the Executive Council of the Society the following were elected members of the Nominating Committee for the ensuing year : Walter S. Surrey, Chairman; Thomas Ehrlich, Alona E. Evans, Benjamin Forman, and Cornelius Murphy.

The Report of the Committee on Publications of the Department of State and of the United Nations was next considered. Mr. JoHN CAREY, Chairman of the committee, made a brief oral report (the full report is printed below, p. 252) and presented the following resolution for adoption by the Society :

\section{Foreign Relations of the United States}

The American Society of International Law at its 63rd Annual Meeting, recognizing the importance of the official publication of the documentary record of American diplomacy in Foreign Relations of the United States as a background for present world problems, and concerned at the increasing delay in the publication of these volumes, the latest of which contain documentation for 1945,

Resolves: To call again upon the Department of State to take effective measures to prevent further widening of the gap between currency and publication of the documentary record in Foreign Relations of the United States and to bring the publication of these 
volumes back to within the twenty-year time limit previously accepted by the Department as a reasonable limit save for exceptional cases involving currently sensitive documents.

After discussion of the problem of the time lag in publication of $U$. S. Foreign Relations, in which it was indicated that a shortage of staff in the State Department rather than lack of money was the principal cause of the delay in publication, along with the time element in obtaining clearance of the material to be published, the motion of Chairman Carey, duly seconded, was carried, and the resolution adopted.

Mr. WILLIAM M. REISMaN thereupon offered the following resolution:

Whereas, International law is committed, in the United Nations Charter, the Universal Declaration of Human Rights and the various human rights conventions, to the development of a world public order of human dignity in which the inherent worth of each individual is a matter of international concern, and

Whereas, Violations of human rights generate tensions and hostilities and precipitate threats to global peace, and

Whereas, International institutions are concerned with establishing competent techniques for protecting minimum standards of human rights throughout the world:

Therefore, $B e$ it Resolved,

That it is the consensus of the American Society of International Law that a committee forthwith be established to be called the Commission for the International Protection of Human Rights; that said Commission for the International Protection of Human Rights shall continuously consider deviations from the standards demanded by the world community and shall study and recommend effective means for protecting and guaranteeing these rights.

$B e$ it Further Resolved, That the first item on the Commission's agenda shall be the problem of Biafra.

The ChaIrMan called the attention of the members to Article VIII of the Society's Constitution under which all resolutions relating to principles of international law or to international relations, which are offered at a meeting of the Society, shall in the discretion of the presiding officer or on the demand of three members be referred to the appropriate committee or to the Council and no vote taken thereon until a report shall have been made. He proposed to refer the resolution to the Society's Board of Review and Development or to the Executive Council. After discussion as to whether the resolution fell within the scope of the constitutional provision cited, and whether it should be referred to the Executive Council or the Board of Review and Development of the Society, it was the sense of the meeting that the resolution be referred to the Executive Council for its consideration.

Mr. JACK GUMPERT WASSERMaN, referring to the desirability of the Society's holding its annual meeting in New York City in 1970, particularly in view of the fact that the 25th anniversary of the United Nations would be observed then, offered a motion that the President of the Society appoint an ad hoc committee to investigate the possibility of holding the 64th 
annual meeting of the Society in the City of New York and that the ad hoc committee report to the Executive Council as to its findings not later than June 1, 1969. After lengthy discussion the motion was made, seconded and carried that the Executive Council investigate the possibility of holding the 64th annual meeting of the Society in the City of New York. A second motion was made, seconded and carried that the Executive Council investigate the question of holding the annual meeting of the Society in other parts of the country from time to time. A number of views were expressed on the question of whether the annual meeting should on occasion be held outside Washington.

With reference to the proposal that the Society's annual meeting in 1970 be held in New York in view of the celebration of the 25th anniversary of the United Nations, Dr. CHarLes G. Fenwick called attention to the purposes of the Society and to the present crisis of the world, and urged that the program of the Society's 1970 annual meeting give emphasis to the United Nations and to the strengthening of the collective forces of law and order under that organization.

Mr. Peter D. Trooboff, former Chairman of the Association of Student International Law Societies, proposed that the Society have one of its existing committees, or appoint a new committee, to act as an advisory group to the Association in order to achieve closer relations between the Society and the Association. A motion was thereupon made, seconded and carried, recommending to the Executive Council of the Society that an appropriate arrangement be made to carry out the suggestion.

There followed comments and criticisms of the meeting arrangements and conduct of the panel sessions under the interrogation system initiated at this year's annual meeting.

The meeting was adjourned at 11:47 o'clock a.m. 